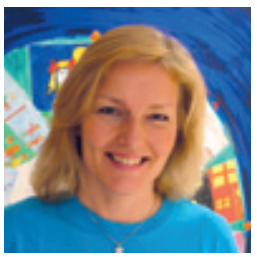

\title{
Den virkelig store forskjellen
}

\section{For fattige mødre er det livsfarlig \\ å føde. Ingen annen enkeltfaktor viser forskjellene mellom fattig og rik som mødredødelighet. Intet annet tema avslører vår politiske og kulturelle handlingslammelse overfor fattig- dommens årsaker som mødredøde- lighet.}

Det er ikke vanskelig å føle seg privilegert når man er så heldig som meg å få lov til å arbeide for UNICEF og hver dag føle at min innsats gjør en forskjell for mange barn. Jeg antar at jeg deler denne gode følelsen av å ha et meningsfullt arbeid med mange av dette tidsskriftets lesere.

Men det er også lett å se at jeg er svært privilegert fordi jeg lever i en verdensdel hvor vi sitter på toppen av kransekaka til tross for finanskrise $-\mathrm{i}$ et land hvor kvinner tas på alvor og stort sett nyter de samme privilegier som menn.

Aldri slår de enorme forskjellene i verden meg sterkere enn når vi får statistikk om kvinnehelse. I forbindelse med inngangen til et nytt tusenår mente Kofi Annan at «the turn of the century» var en passende anledning til nye visjoner og løfter om en bedre fremtid for verden. Han fikk med seg 160 av verdens ledere til å underskrive millenniumsdeklarasjonen. Den besto av åtte konkrete løfter for å bekjempe fattigdom som hver nasjon har forpliktet seg til å jobbe for å innfri innen 2015.

Det virker faktisk! Enkelte av løftene kommer til å bli innfridd. For mange av løftene når man ikke målene, men det har vært en betydelig fremgang. Men på ett felt har fremgangen vært lik null. Det dør fremdeles like mange kvinner i dag som i 1990, selv om løftet var å redusere antall kvinner som døde i barsel med 3/4 innen 2015.

Hvert minutt dør en kvinne i barsel. $99 \%$ av dem er fattige kvinner. Det er faktisk over tusen ganger større risiko for å dø av fødselsrelaterte sykdommer i Niger enn i Norge. Ingenting viser skillet mellom rik og fattig så klart som mødredødelighet.

En halv million mødre dør i forbindelse med fødsel. Ti millioner får alvorlige skader - og lite har skjedd de siste ti årene.

Kvinner trenger utdannet helsepersonell og helsestasjoner i sitt nærområde. Fattige kvinner har verken økonomi eller tillatelse fra ektemannen til å reise langt hvis de er syke. Mangelen på et helsetilbud er hovedårsaken til småbarns og mødres høye dødsfall.

Familieplanlegging er et vanskelig politisk og kulturelt tema som man gjerne unngår å snakke om. Uten økt familieplanlegging vil fattige kvinners liv fortsatt stå i fare ved fødsler. Det mangler mot til å snakke om familieplanlegging.

Det er umulig ikke å se manglende hand- ling i forhold til mødre- og kvinnehelse som noe annet enn en konsekvens av at kvinner har altfor lav økonomisk, sosial og politisk status. Intet land, ikke engang Niger, ville godtatt en slik statistikk for fedre.

UNICEF har fokusert på problemet $i$ årevis. Men at det er et faktum at tusenvis av kvinner dør i barsel og at kvinner har rettigheter, er tydeligvis ikke et godt nok budskap. Vi må definitivt i større grad snakke om penger. Verdens ledere må tydeligere vises de økonomiske gevinstene av bedre helsetjenester og økt familieplanlegging. Finanskrisen har med all tydelighet vist oss at når penger er problemet, øker innsatsen fra verdens regjeringer. For å løse denne kristen bevilges det nå beløp som vi aldri i vår villeste fantasi kunne drømt om til kriser som handler om miljø, helse eller fattigdom. Vi må tydeligvis sammen vise at vi sparer penger, mange penger, ved å satse på kvinnehelse. Foruten at vi da også kan redde en mor i minuttet.

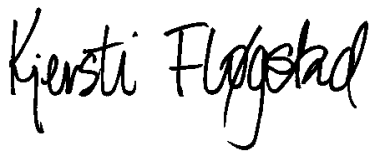

\section{I neste nummer:}

\author{
Kirurgi uten arr \\ Myalgisk encefalopati \\ CRP ved hjerte- og karsykdom
}

Sosial ulikhet i dødelighet

Warfarin

Subaraknoidalblødning 